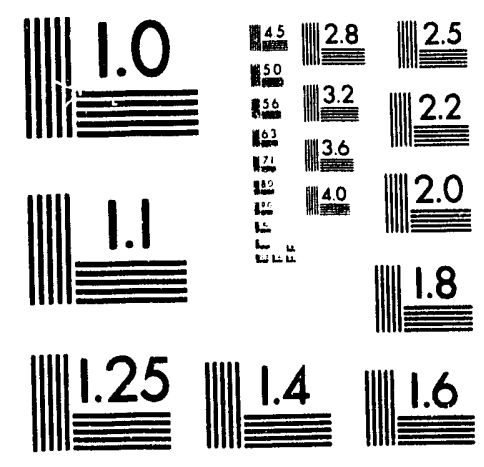



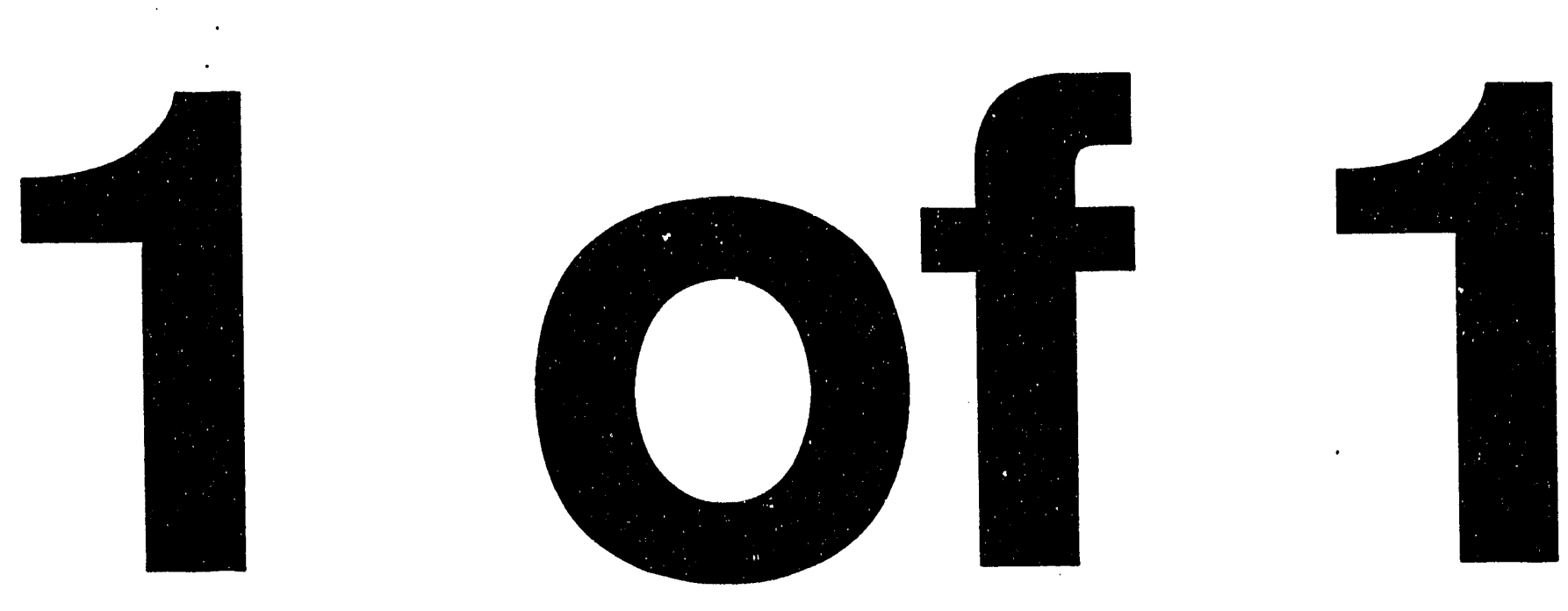
PNL-SA-21290

PROPERTIES AND POTENTIAL OF

HIGH-TEMPERATURE NIOBIUM BERYLLIDES
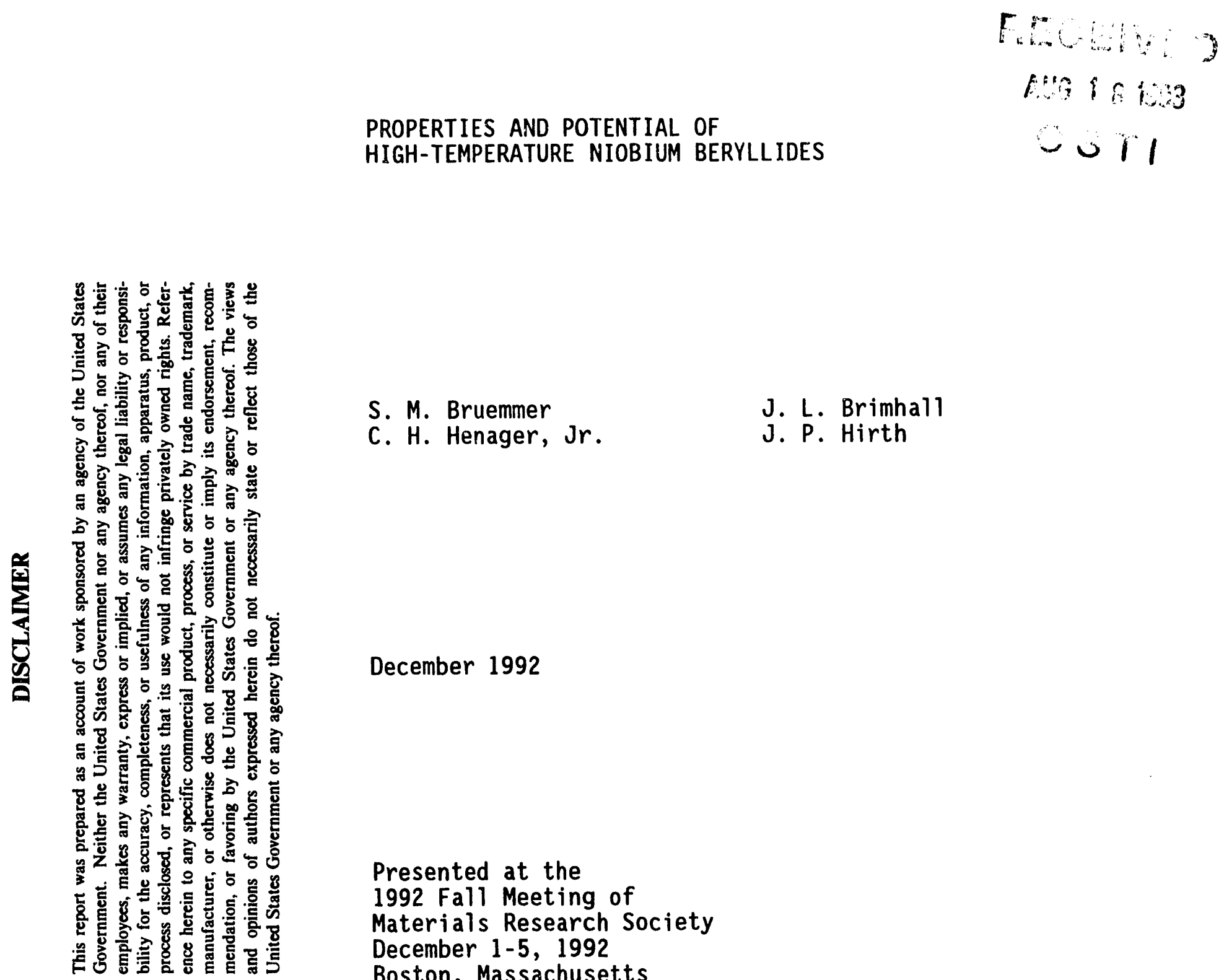
S. M. Bruemmer
J. L. Brimhall
C. H. Henager, Jr.
J. P. Hirth

December 1992

\author{
Presented at the \\ 1992 Fall Meeting of \\ Materials Research Society \\ December 1-5, 1992 \\ Boston, Massachusetts \\ Prepared for \\ the U.S. Department of Energy \\ Contract DE-AC06-76RLO 1830 \\ Pacific Northwest Laboratory \\ Richland, Washington 99352
}




\title{
Properties and Potential of High-Temperature Niobium Beryllides
}

\author{
S. M. Bruemmer, J. L. Brimhall, C. H. Henager, Jr. and J. P. Hirth' \\ Pacific Northwest Laboratory, Richland, WA 99352 \\ -Washington State University, Pullman, WA 99164
}

\begin{abstract}
Recent research on the low- and high-temperature properties of two beryllium-niobium intermetallic compounds, $\mathrm{Be}_{12} \mathrm{Nb}$ and $\mathrm{Be}_{17} \mathrm{Nb}_{2}$, is reviewed and discussed. Strength (bend and compression), hardness and fracture toughness has been mapped as a function of test temperature up $101200^{\circ} \mathrm{C}$. Results for hot-isostatically-pressed $\mathrm{Be}_{12} \mathrm{Nb}$ and $\mathrm{Be}_{17} \mathrm{Nb}_{2}$ are highlighted illustrating the potential for reasonable strength at both low and high temperatures. Chemical compatability between $\mathrm{Be}_{12} \mathrm{Nb}$ and several high-temperalure materials such as $\mathrm{SiC}, \mathrm{Al}_{2} \mathrm{O}_{3}, \mathrm{MoSi}_{2}$ and various refractory metals are evaluated. Limilations for the struclural use of the beryllides are identified and discussed including low-temperature loughness, intermediate-temperature embrittement, high-temperature creep strength and composite compatability.
\end{abstract}

\section{Introduction}

Beryllium-refractory metal intermelallic compounds, i.e. $B e_{12} X, B e_{13} X$ and $B e_{17} X_{2}$, exhibit excellent strength and oxidation resistance at high temperatures. Because of these properties and their very low densities, beryllides are promising candidate materials for aerospace application. The combination of properties exceeds other intermetallics such as refractory metal silicides and aluminides in most cases. Unfortunately, similar to many other intermetallics, beryllides have complex crystal structures which lead to poor low-temperature loughness.

The $\mathrm{Be}_{12} \mathrm{X}$ compound is the simpliest with a body-centered-tetragonal (bct) structure $(14 / \mathrm{mmm})$ and 26 atoms per unit cell. Elements such as $\mathrm{Nb}, \mathrm{Mo}, \mathrm{Ta}, \mathrm{Ti}, \mathrm{Cr}, \mathrm{V}$ and $\mathrm{W}$ all form isostructural $\mathrm{Be}_{12} \mathrm{X}$ compounds with little change in the lattice dimensions. $A$ number of metallic elements also form isostructural $\mathrm{Be}_{13} \mathrm{X}$ (cubic, $\mathrm{Fm} 3 \mathrm{C}$ ) and $\mathrm{Be}_{17} \mathrm{X}_{2}$ (hexagonal-rhombahedral, $\mathrm{R} 3 \mathrm{~m}$ ) compounds as summarized in Figure 1. Phase stability in beryllides (e.g., formation of $\mathrm{Be}_{13} \mathrm{X}$ versus $\mathrm{Be}_{12} \mathrm{X}$ ) depends on atom size of the metal atom $(X)$ reacling with $B e$ and, to a lesser extent, its bonding character. 1 Face-centered-cubic ( $f c c) B e_{13} X$ is favored when the diameter of metal atom $\left(d_{X}\right)$ is greater than $\sim 0.3 \mathrm{~nm}$, while $B e_{12} X$ is stable for smaller atom sizes, $d_{x}=0.25$ to 0.29 $\mathrm{nm}$. Among the $\mathrm{Be}_{12} \times$ compounds, larger $(>0.28 \mathrm{~nm}$ ) metal atoms (e.g., $\mathrm{Nb}, \mathrm{Ta}$ and $\mathrm{Ti})$ also form $\mathrm{Be}_{17} \mathrm{X}_{2}$, but smaller ones (e.g., Cr, Mn, V, Mo and $\mathrm{W}$ ) do not.

Recent work by the authors on $\mathrm{Be}_{12} \mathrm{Nb}$ and $\mathrm{Be}_{17} \mathrm{Nb}_{2}$ intermetallics is reviewed with emphasis on: (1) phase stability, (2) mechanical properties, (3) deformation mechanisms and (4) composite compatabilty. Specific properties of these compounds are discussed in relation to their polential for high-temperature structural applications. 
until the average size of the $\mathrm{Nb}+\mathrm{Zr}$ atoms reaches a critical value at which point the $\mathrm{Be}_{13} \mathrm{X}$ phase furms. Relative stabilities between the various stable and metastable crystal structures is believed to play an important role in the deformation behavior and mechanical pruperties of $\mathrm{Be}_{12} \mathrm{X}$ compounds as discussed in the following sections.

\section{Mechanical Properties}

\section{Bend Strength and Fracture Toughness}

Four-point-bend and chevron-notch-bend specimens have been used to determine strength and toughness of VHP and HIP beryllides. 8 -10 HIP $\mathrm{Be}_{12} \mathrm{Nb}$ exhibited the best properties in bending with strengths of $210-250 \mathrm{MPa}$ measured at $20^{\circ} \mathrm{C}$ to $650^{\circ} \mathrm{C}$ (Figure 2). Strength dropped sharply from $650^{\circ} \mathrm{C}$ to $900^{\circ} \mathrm{C}$, and then increased to $\sim 250 \mathrm{MPa}$ at higher temperatures. Limited plasticity was observed below $1100^{\circ} \mathrm{C}$. At low temperatures, a fine, granular fracture surface is observed consisting of intergranular (IG) facets and small cleavage regions across individual grains. The fracture surface became britlle intergranular and macroscopicly flat at temperatures from $800^{\circ} \mathrm{C}$ to $1000^{\circ} \mathrm{C}$. Temperature effects on fracture toughness closely matched the bend strength resulls as shown in Figure 2. Low-temperature $K_{1 C}$ ranged from 4 to 4.6 MPaV/m corresponding to the highest measured bend strengths. Toughness values decreased to less than $0.5 \mathrm{Mpa} / \mathrm{m}$ at intermediate temperatures before increasing above $900^{\circ} \mathrm{C}$. This embrittlement occurs at temperatures where accelerated oxidation (pest) is seen in static tests, but cannot be directly linked to the fracture process. 11

HIP $\mathrm{Be}_{17} \mathrm{Nb}_{2}$ exhibited only elastic behavior in bend tests at all temperatures up to $1100^{\circ} \mathrm{C}$. Slight inelastic deflection was observed at $1100^{\circ} \mathrm{C}$ and measurable plastic deformation was seen at $1200^{\circ} \mathrm{C}$. Bend stiengths increased from $100 \mathrm{MPa}$ at $20^{\circ} \mathrm{C}$ to a maximum of $740 \mathrm{MPa}$ at $1100^{\circ} \mathrm{C}$ (Figure 2). High-temperature strengths for $\mathrm{Be}_{17} \mathrm{Nb}_{2}$ at were much greater than for $\mathrm{Be} e_{12} \mathrm{Nb}$. Measured $\mathrm{K}_{1 \mathrm{C}}$ for $\mathrm{Be}_{17} \mathrm{Nb}_{2}$ material was less than $2.5 \mathrm{MPa} \sqrt{\mathrm{m}}$ at test temperatures below $1100^{\circ} \mathrm{C}$, which indicates that the measured bend strengths are limited by the toughness of the material. $\mathrm{Be}_{17} \mathrm{Nb}_{2}$ failed by transgranular cleavage (flat, featureless appearance) with no obvious IG features.

\section{Compression Strength}

Compression tests have been performed on various beryllide heats using small cylindrical or cube specimens.9.10 A maximum uniaxial compressive strength of $2750 \mathrm{MPa}$ was measured for the HIP $\mathrm{Be}_{12} \mathrm{Nb}$ at $20^{\circ} \mathrm{C}$. Strength remained quite high $\left(2380 \mathrm{MPa}\right.$ ) at $800^{\circ} \mathrm{C}$ and then decreased rapidly at temperatures greater than $1000^{\circ} \mathrm{C}$ (Figure 3). Compression strengths at temperatures from $20^{\circ} \mathrm{C}$ to $800^{\circ} \mathrm{C}$ were significantly improved over that for $\mathrm{Be}_{17} \mathrm{Nb}_{2}$. Plasticity was indicated from nonlinearities in the load-displacement curves for $\mathrm{Be}_{12} \mathrm{Nb}$ at $-800^{\circ} \mathrm{C}$, while $\mathrm{Be}_{17} \mathrm{Nb}_{2}$ revealed brittle behavior at temperatures up to $1000^{\circ} \mathrm{C}$. Ambient temperature strength for $\mathrm{Be}_{17} \mathrm{Nb}_{2}$ was only $1200 \mathrm{MPa}$, less than one-half that for the HIP $\mathrm{Be}_{12} \mathrm{Nb}$. Strength increased with temperature, reaching a maximum value of $1550 \mathrm{MPa}$ at $800^{\circ} \mathrm{C}$ (Figure 3). A very low strength of $400 \mathrm{MPa}$, below that for $\mathrm{Be}{ }_{12} \mathrm{Nb}$, was measured at $1000^{\circ} \mathrm{C}$. Compressive strength at $1200^{\circ} \mathrm{C}$ was identical to $\mathrm{Be}_{12} \mathrm{Nb}$ ( $200 \mathrm{MPa})$, in contrast to the higher strength observed in the bend tests. 


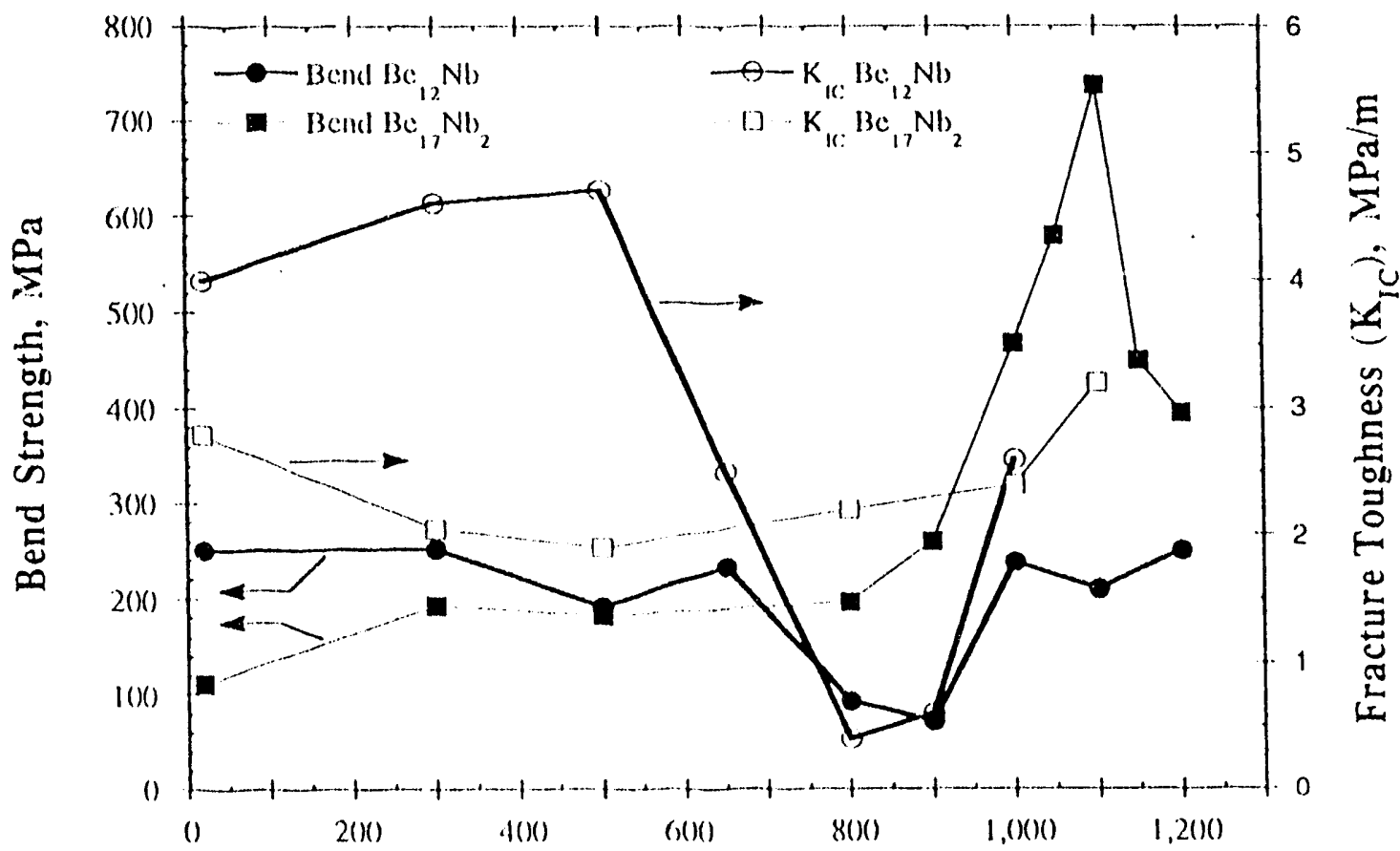

'Test Temperature, $C$

Figure 2. Bend Strength and Fracture Toughness for HIP $\mathrm{Be}_{12} \mathrm{Nb}$ and $\mathrm{Be}_{17} \mathrm{Nb}_{2}$ Compounds.

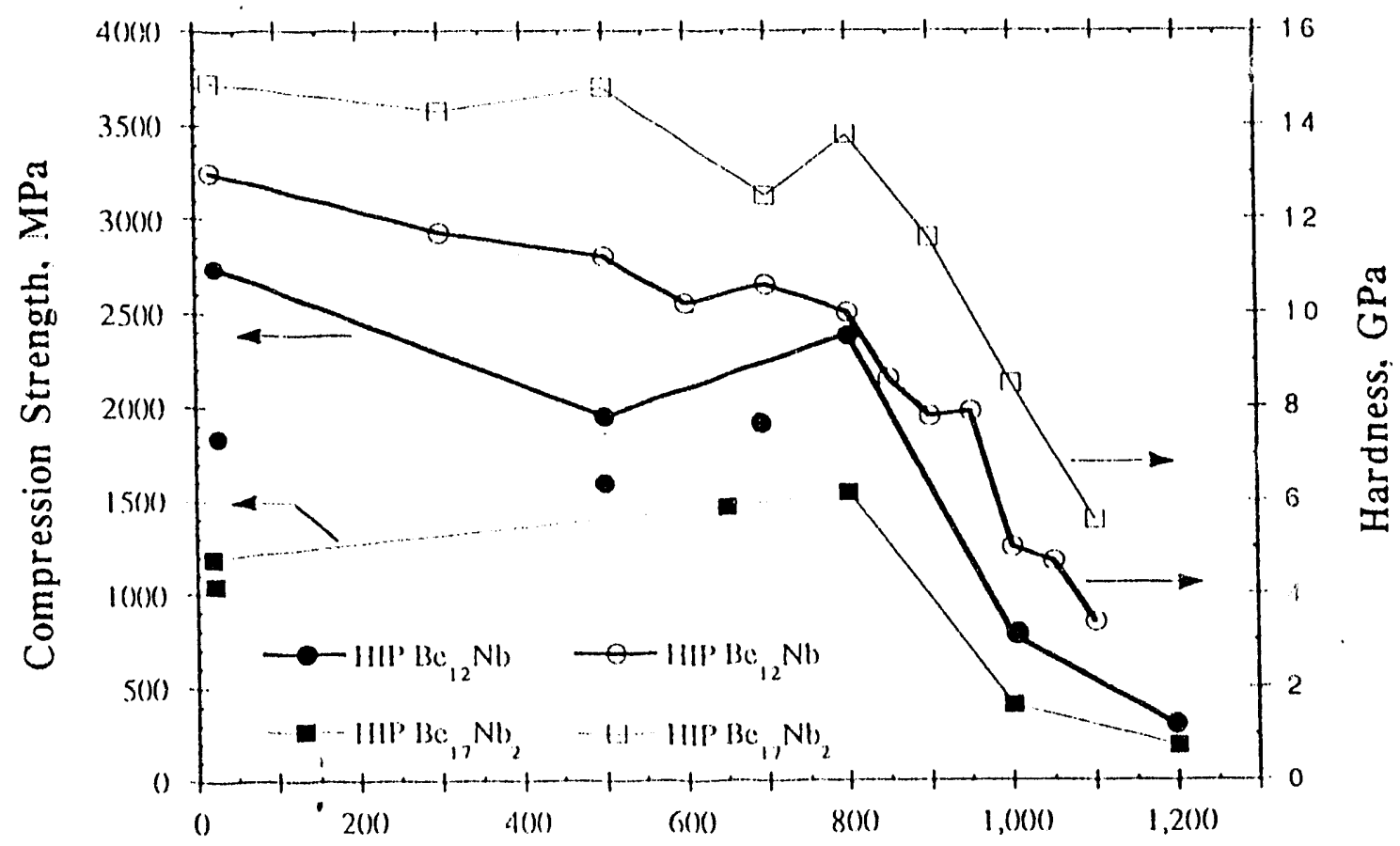

'l'est 'Temperalure, C

Figure 3. Compression Strength and Hot Hardness for HIP $\mathrm{Be}_{12} \mathrm{Nb}$ and $\mathrm{Be}_{17} \mathrm{Nb}_{2}$ Compounds. 
High-Temperature Microhardness and Indentation Creep Tests

High-temperature microhardness tests have been performed on VHP and HIP $\mathrm{Be}_{12} \mathrm{Nb}$ and $\mathrm{Be}_{17} \mathrm{Nb}_{2}$ heats $10,12,13$ and on several isostructural VHP $\mathrm{Be}_{12} \mathrm{X}$ materials. 12 HIP heats showed a higher hardness than VHP heats at temperatures below $200^{\circ} \mathrm{C}$, due to their finer grain size and reduced porosity. The largest difference was observed at $20^{\circ} \mathrm{C}$ where the HIP materials show hardness values from 12.8 GPa to $14.0 \mathrm{GPa}$, while hardness for the VHP materials range from 8.8 $\mathrm{GPa}$ to $9.8 \mathrm{GPa}$. Hardness results for $\mathrm{Be}_{17} \mathrm{Nb}_{2}$ were consistently above that for $\mathrm{Be}_{12} \mathrm{Nb}$ (Figure 3) with a maximum difference of $3 \mathrm{GPa}$ occurring at $800^{\circ} \mathrm{C}$ to $950^{\circ} \mathrm{C}$ Test temperatures of about $1000^{\prime \prime} \mathrm{C}$ were required before a significant decrease in hardness was observed, a slightly higher transition than for $\mathrm{Be}_{12} \mathrm{Nb}\left(\sim 850^{\circ} \mathrm{C}\right)$. Differences in ductile-brittle transition behavior between $B e_{12} X$ compounds $(\mathrm{Cr}, \mathrm{Mn}$. $\mathrm{Ti}, \mathrm{Mo}, \mathrm{V}, \mathrm{Ta}$ and $\mathrm{Nb}$ ) were observed and related $10 \mathrm{Be}{ }_{12} \mathrm{X}-\mathrm{Be}{ }_{17} \mathrm{X}_{2}$ phase stability. Elements such as $V$ and $M o$ (which form $B e_{12} X$, bilt not $B e_{17} X_{2}$ ), were found to exhibit lower transition temperatures. Secondary slip systems were found to be activated in $\mathrm{Be}_{12} \mathrm{~V}$ at temperatures $\sim 300^{\circ} \mathrm{C}$ below that for $\mathrm{Be}_{12} \mathrm{Nb}$ even though both compounds have similar melting temperatures. 13

Indentation creep tests were performed on $\mathrm{Be}_{12} \mathrm{Nb}$ and $\mathrm{Be}{ }_{17} \mathrm{Nb}_{2}$ materials using the high-temperature microhardness tester and varying the indentation dweil time. This data was used to calculate creep parameters for this material.10.12 Power-law creep exponents of 4.3 and 4.1 were determined for the HIP $\mathrm{Be}_{12} \mathrm{Nb}$ and VHP $\mathrm{Be}_{17} \mathrm{Nb}_{2}$, respectively. Activation energies for dislocation creep were abour $290 \mathrm{~kJ} / \mathrm{mole}$ for HIP $\mathrm{Be}_{12} \mathrm{Nb}$ and $230 \mathrm{~kJ} / \mathrm{mol}$ for VIIP $\mathrm{Be}_{17} \mathrm{Nb}_{2}$. $\mathrm{Be}_{17} \mathrm{Nb}_{2}$ required a slightly higher temperalure $\left(950^{\circ} \mathrm{C}\right)$ for the transition to power.law creep as compared to that for $\mathrm{Be}_{12} \mathrm{Nb}$. Although individual hardness values were consistently higher for $\mathrm{Be}{ }_{17} \mathrm{Nb}_{2}$, the rate of change with temperalure was quite similar to that for $\mathrm{Be}_{12} \mathrm{Nb}$. Specific properlies for $\mathrm{Be}_{12} \mathrm{Nb}$ and $\mathrm{Be}_{17} \mathrm{Nb}_{2}$ are summarized in Table 1.

Table 1. Selected Properties for $\mathrm{Be}_{12} \mathrm{Nb}$ and $\mathrm{Be}_{17} \mathrm{Nb}_{2}$ Intermetallics

\begin{tabular}{|c|c|c|}
\hline Propenty & $\mathrm{Be}_{12} \mathrm{Nb}$ & $\mathrm{Be}_{17} \mathrm{Nb}_{2}$ \\
\hline Crystal Structure & tetragonal & rhomohedral \\
\hline Melting Ternperature, ${ }^{\circ} \mathrm{C}$ & 1672 & 1800 \\
\hline Density, $\mathrm{g} / \mathrm{cm}^{3}$ & 2.9 & 3.2 \\
\hline Elastic Modulus, GPa & 220 & 320 \\
\hline \multicolumn{3}{|l|}{ Maximum Strength at $23^{\circ} \mathrm{C}$} \\
\hline - Bending, MPa & 250 & 110 \\
\hline - Compression, MPa & 2750 & 1200 \\
\hline - Hardness, GPa & 13.7 & 14.9 \\
\hline \multicolumn{3}{|l|}{ Maximum Strength at $1200^{\circ} \mathrm{C}$} \\
\hline - Bending, MPa & 250 & 390 \\
\hline - Compression, Mpa & 295 & 190 \\
\hline - Hardness $\left(1100^{\circ} \mathrm{C}\right), \mathrm{GPa}$ & 3.8 & 5.8 \\
\hline \multicolumn{3}{|l|}{ Ductile-Brittle Transition Temperature, ${ }^{\circ} \mathrm{C}$} \\
\hline - Bending & $\sim 1100$ & $\sim 1100$ \\
\hline - Harness & $\sim \delta 50$ & $\sim 900$ \\
\hline Activation Energy for Dislocation Creep, $\mathrm{kJ} /$ mole & 290 & 230 \\
\hline
\end{tabular}


6. J.L. Brimhall, L.A. Charlot and S.M. Bruemmer, High-Temperature Ordered Intermetallic Alloys, Materials Research Society, 1991, p. 175.

7. J.L. Brimhall, L.A. Charlot and S.M. Bruemmer, Mater. Sci. Eng., A152 (1992) 76.

8. C.H. Henager, Jr., R.E. Jacobson and S.M. Bruemmer, Mater. Sci. Eng., A152 (1992) 416.

9. S.M. Bruemmer, B.W. Arey and C.H. Henager, Jr., Intermetallic Matrix Composites II, MRS Spring Meeling. Materials Research Society, 1992.

10. C.H. Henager, Jr., J.P. Hirth and S.M. Bruemmer, submitted to Mat. Sci. Eng., 1992

11. S.M. Bruemmer and L.A. Charlot, submitted to Scripta Metall. et Mat., 1992

12. R.E. Jacobson, High Temperature Strength and Creep Resistance of $\mathrm{Be}{ }_{12} \mathrm{Nb}$ and $\mathrm{Be}_{17} \mathrm{Nb}_{2}$ Intermetallics, Masters Thesis, Washington State University, 1991.

13. S.M. Bruemmer, B.W. Arey, J.L. Brimhall and J.P. Hirth, submitted to J. Mater. Research, 1992.

14. S.M. Bruemmer, L.A. Charlol, J.L. Brimhall, C.H. Henager, Jr., and J.P. Hirth, Phil. Mag. A, 65 (1992) 1083.

15. S.M. Bruemmer, L.A. Charlot, C.H. Henager, Jr., and J.P. Hirth, submitted to Scripta Metall., 1992.

16. L.A. Charlot, J.L. Brimhall, L.E. Thomas, S.M. Bruemmer and J.P. Hirth, Scripta Metall., 25 (1991) 99.

17. B.A. Greenberg, O.V. Antonova, V.N. Indenbom, L.E. Karkina, A.B. Notkin, M.V. Panomarev and L.V. Smirnov, Acta Metall., 35 (1991) 233.

18. M.L. Kronberg, J. Nucl. Mater., 1 (1959) 85.

19. S. Sondhi, R.G. Hoagland, J.P. Hirlh and S.M. Bruemmer, High-Temperature Ordered Intermetallic Alloys, Materials Research Society, submitted 1992.

20. J.L.. Brimhall and S.M. Bruemmer, Scripta Metall, in press, 1992.

\section{Acknowledgements}

Contributions of R. Jacobson, S. Sondhi, L. A. Charlot and B. W. Arey, as well as critical discussiuns with R. G. Hoagland, are acknowledged. Work is supported by the Defense Advanced Research Projects Agency through the Office of Naval Research and under U.S. Department of Energy contract DE-AC06-76RLO 1830 with Pacific Northwest Laboratory, which is operated by Battelle Memorial Institute. 

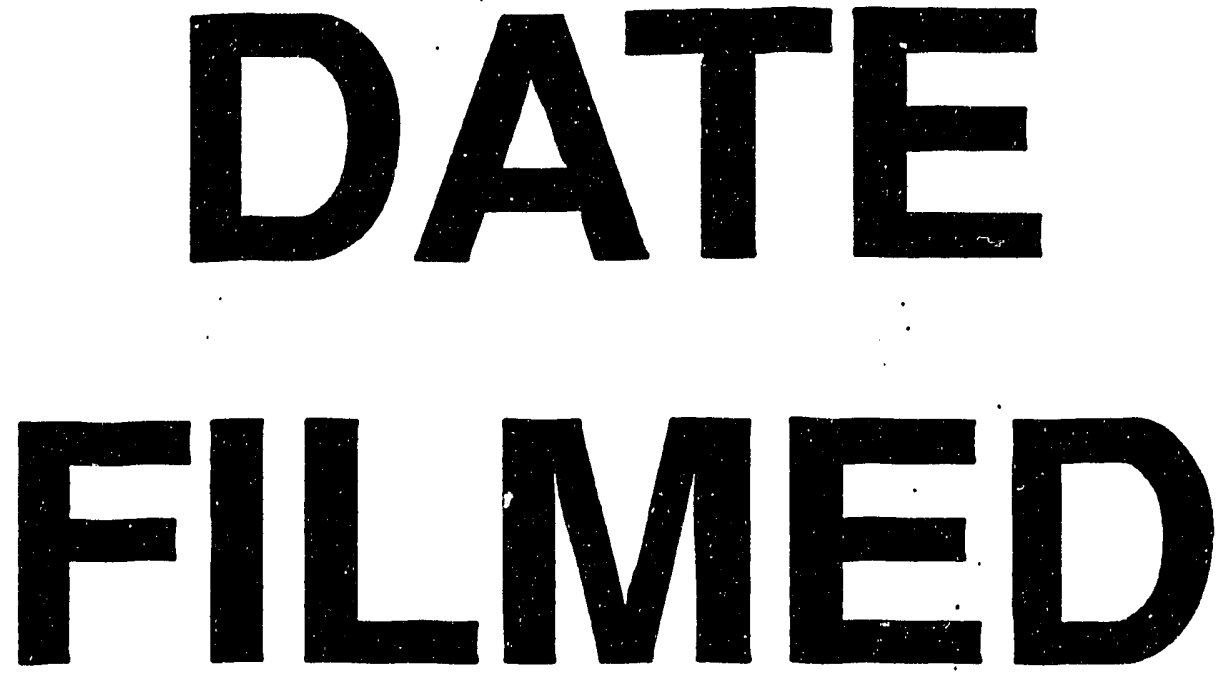

$10 / 20 / 93$
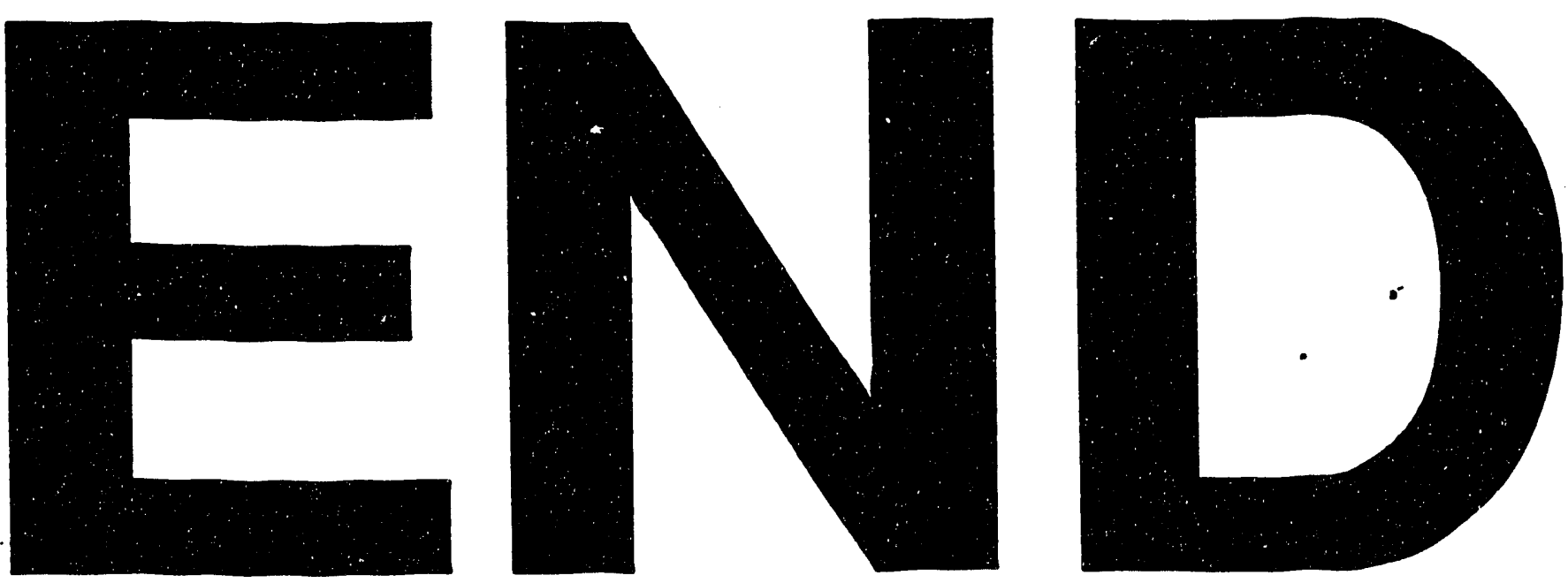
